\title{
THE IMPACT OF STANDARD VALUE ADDED TAX ON ECONOMIC GROWTH IN CEE-5 COUNTRIES: ECONOMETRIC ANALYSIS AND SIMULATIONS
}

\author{
Mihaela SIMIONESCU, Lucian-Liviu ALBU \\ Institute for Economic Forecasting, Romanian Academy, 13, \\ Calea 13 Septembrie, District 5, Bucharest, Romania
}

Received 24 August 2016; accepted 1 October 2016

\begin{abstract}
The value added tax (VAT), as an instrument of fiscal policy, might have an important role on economic growth. This study analyzes the impact of standard VAT rate on economic growth in five Central and Eastern European countries (CEE-5) (Bulgaria, Czech Republic, Hungary, Poland and Romania). Different types of panel data models (random effect model, dynamic panel and panel vector-autoregression) over 1995-2015 indicated a positive influence of VAT rate on economic growth. There is a bilateral Granger causality between economic growth and VAT rate. The Bayesian linear models indicate a positive effect of VAT rate on GDP rate only for Hungary. On short-run, the other countries register lower GDP rates when VAT rates increase. Some simulations of economic growth for 2016 and 2018 were made for each CEE- 5 country under different assumptions regarding VAT rate values.
\end{abstract}

Keywords: VAT rate, panel data, Bayesian model, economic growth.

JEL Classification: C51, C53, H20.

\section{Introduction}

This research focuses on the impact of standard VAT rate on economic growth in five Central and Eastern European countries (Bulgaria, Czech Republic, Hungary, Poland and Romania). The methods used to analyze this relationship are represented by econometric techniques covering both parts of Econometrics: traditional approach (panel data models) and Bayesian approach (Bayesian linear regressions). These methods were employed to solve the problem of short data series. Other studies from literature used alternative methods like simple linear regression, discriminant analysis or ANOVA procedure, but the small sets of data make these methods unsuitable in our study (Unegbu, Irefin 2011; Njogu 2015).

Corresponding author Mihaela Simionescu

E-mail:mihaela_mb1@yahoo.com 
Different types of panel data models over 1995-2015 indicated a positive impact of VAT rate on economic growth in CEE-5 countries. On the other hand, the individual Bayesian models showed a low negative impact of VAT rates on GDP rates in Bulgaria, Czech Republic, Poland and Romania. Moreover, some simulations of real GDP rate were made for 2016 and 2018 under different assumptions regarding standard VAT rate. According to Bayesian approach, the gradual decrease in VAT rates in Romania, according to the revised fiscal law, will generate higher GDP rates in 2016 and 2018.

\section{Literature survey}

The value added tax (VAT) represents an essential instrument in fiscal policy in any country. It is an important income source of the state budget.

Every person should pay VAT while buying most goods and services. This tax is in practice imposed in entire world. The VAT principle refers to the supplier that is registered as prayer. In case if trade is subject to taxation, this one has to pay a part of executed trade value to the state.

VAT importance covers two levels: common European market and national markets. Therefore, the European Commission is interested in the harmonization of VAT rates in EU countries. The harmonization process is based on the directive that fixed the principal determinants of the common VAT system in EU. The efficiency of VAT rates should be maximized following the tax experts' recommendations in order to create the common VAT system. Moreover, a single rate should be proposed, only few exemptions and a broadly tax base. For some services and goods only two reduced rates are required, with values that are not lower than 5\%. In EU, this harmonization process was complex and very long. The theoretical framework is still affected by many transitional provisions. On the other hand, there are many special exemptions from European Commission common rules that are accorded in an individual way to EU countries.

In VAT tax competition, there are issues on labour taxes. Member states with lower income taxes and little social security contributions are not preferred by employees. Lower work efforts and high production costs indicate the efficiency effects on labour taxes (Cnossen 2002).

The most part of studies regarding VAT rates and their effect on tax revenue are not related to the policy aspects of reduced rates. The difference between present VAT revenues and theoretical VAT revenues is computed, if total final private consumption by are to be taxed at the standard rate of VAT. This difference is influenced by other factors like exemption, fraud, registration thresholds, tax avoidance and certain VAT schemes like flat-rate taxation and margin schemes.

Two types of VAT rates are calculated by the European Commission: implicit tax rate on consumption (total VAT revenue on consumption which is computed as percentage of potential tax base) and reduced VAT rate and base indicator, which is the difference between the usual VAT rates and the VAT component corresponding to the implicit tax rate on consumption. Other factors influence these rates by reducing the VAT revenues. EU allows at most two reduced rates and the lowest one should be $5 \%$ or more. According 
to the Directive of EU Member States, the minimum limit for standard rate of VAT is 15\% (Borselli et al. 2012).

VAT gap was computed by Reckon who compared actual VAT receipts with theoretical net VAT liability (Reckon 2009). The VAT gap includes VAT fraud and the revenue losses determined by tax avoidance schemes or insolvencies. The confidence in results depends on the completeness and accuracy of the Member States' national accounts. A regression analysis was performed to identify the determinants of VAT Gap in 24 countries of EU (Zídková 2014) (final private consumption and the non-profit organizations consumption, size of shadow economy, number of VAT taxes, share in intra-community trade, final consumption of hotel services and restaurants).

Michela Redoano (2014) analyzed the effect of EU membership on capital tax competition inside European states. Tax competition is not an urgent issue for EU countries (Baskaran, da Fonseca 2014).

Steffen Osterloh and Friedrich Heinemann employed a survey to show that few variables determine if European Parliament members support a minimum corporate tax (Osterloh, Heinemann 2013). In EU, even if there is not a conventional taxing power, Philipp Genschel, Achim Kemmerling, and Eric Seils showed that there is a large regulatory power over national taxation (Genschel et al. 2011).

In literature the tax competition is often studied using econometric techniques. For example, Benassy-Quere, Fontagne and Lahreche-Revil studied for a panel of 11 OECD states the impact of statutory corporate tax rate on foreign direct investment and the results showed an imperfect competition (Bénassy-Quéré et al. 2005). A strong impact of taxes on FDI was observed by Guntram B. Wolff (Wolff 2007). Difference-in-difference regressions are employed by Inga Rademacher to compare EMU countries with non-EMU ones (Rademacher 2013). Mostly small EMU states are engaged in the tax competition. During the European integration, in small EMU countries the average tax rates decreased while they increased in ones. Corporate tax rates had a significant impact on FDI inward stock in several countries from South Europe during 2000-2011, as Ines Kersan-Škabić obtained using a panel data analysis (Kersan-Škabić 2015).

Spatial econometric models are also employed to analyze the local tax competition on global level. The authors checked if tax rate in a certain country is affected by the rates in neighbouring countries. For 21 countries of OECD, Michael Devereux, Ben Lockwood and Michela Redoano showed that they compete over corporate tax rates in case of open economies are open (Devereux et al. 2008). Therefore, tax competition did not decrease national revenues. Inside Europe, Friedrich Heinemann, Michael Overesch, and Johannes Rincke explained that the states react quickly neighbours' tax rates (Heinemann et al. 2010). The interaction between USA and European countries was analyzed by Rosanne Altshuler and Timothy J. Goodspeed over the period from 1968 to 1996 (Altshuler, Goodspeed 2003). Among European states the corporate tax rates competition decreased in the mentioned period. Peter Egger, Michael Pfaffermayr, and Hannes Winner proposed a spatial panel model and they showed that VAT rates are in fact strategic complements (Egger et al. 2005). All the countries have the same benefits regarding tax coordination, because smaller country have the tendency to fix smaller VAT rates compared to their larger counterparts. 
According to Robert Carroll, an increase in VAT will cause a decrease in GDP for a period of several years (Carroll 2010). A significant contribution of VAT on economic growth was observed in Nigeria (Umeora Chinweobo 2013; Onwuchekwa, Aruwa 2014) using linear regression models. A positive impact of VAT on economic growth was also reveled in Ethiopia during 2003 to 2012 using theoretical and empirical evidence (Jalata 2014).

For 14 developed countries the panel data models were used by to identify the trends in economic growth when the VAT rates change (Miki 2011). Before the rise in VAT rate, the economic growth increases. As soon as the rise in VAT rate is applied, the GDP rate suddenly decreases. The economic growth gradually increases after the dramatic decrease.

\section{Value added taxes (VAT) harmonization}

The treaty of Rome established that the taxation harmonization is necessary for the EU members, but in practice the harmonization proposals made little progress. In 1977, the adoption of the Sixth directive harmonized the VATs in EU. Border controls were eliminated in 1992 and a deferred payment system and transitional regime were introduced. In order to control the VAT on acquisition and supply of goods the VAT Informational Exchange System was fixed. In 1987 and 1989 two draft directive were proposed by European Commission to introduce origin principle instead of destination principle and to propose a two-rate VAT system (Keen, Konrad 2014).

An European Commission directive was adopted by the European Council in 1999 to grant an option to European Union states that want to apply a reduced VAT rate to several labour services in the next few years (2000-2002). The aim of this procedure is to increase demand for these particular services and to stimulate employment. The activities refer to:

- Repairs and renovation to private housing;

- Small repairs to leather articles, clothing, footwear, household linens and bicycles;

- Cleaning of private homes and window washing;

- Hairdressing;

- Home health care.

Only 9 countries took advantage of this opportunity: England (only Isle of Man), France, Belgium, Greece, Luxembourg, Italy, Spain, Portugal, Netherlands.

There are, in average, higher effective tax rates on consumption in European Union than in OECD countries. The explanation is given by the fact that the tax mix relies mainly on consumption taxes. VAT rate plays a central role, accounting for major part of the total tax revenues on services and goods in EU. There are some advantages of heavy reliance on these consumption taxes:

- Consumption taxes do not affect external competitiveness and these taxes do not discriminate between locally-realized goods and imports;

- These taxes are relatively neutral towards investment and saving decisions;

- Consumption taxes make a symmetric treatment of capital income, transfer and labour. 
However, exemptions and rate differentiation bring neutrality and lower efficiency of taxes on consumption. Many of the EU states maintained exemptions or reduced taxes for VAT, fact that brought revenue losses. Distributional considerations are described by these taxes. If the VAT rate differentiation is large, it brings large dead-weight losses. Rate differentiation decreases in an indirect way the VAT efficiency by adding up a higher degree of system complexity and by making difficult the assessment of tax compliance. In 1998, the effective rates were less than standard rates, mostly in Sweden, Spain and Belgium. In order to diminish the compliance costs for small firms, turnover thresholds were introduced for which the VAT registration is not required. Simple regimes and presumptive methods were used to determine the tax liability. Therefore, it was difficult to control the compliance, introducing tax avoidance by dividing the firms into lower units and reporting lower sales. In Italy, requiring small firms to register for VAT determined global compliance with tax legislation.

Exemptions and differentiated rates can affect the competition and the patterns in consumption inside the EU states. The privileged catering tax treatment compared to restaurant services is an example. In other situations, competition was introduced in the economic sectors that were controlled by public power: gas, electricity and water supply, telecommunication and postal services, television and radio broadcasting services. There is not a high influence of differences in VAT rates regarding consumption choices. A lower variation of VAT rates was observed in the harmonization efforts made in 1980s and at the beginning of 1990s. There was not a definite spontaneous trend towards harmonization since 1993 in EU countries.

The fast development of electronic commerce transactions affected the possible nonneutralities in the VAT system. A high discrimination regarding EU online sellers was observed, because important distortions were brought to international procedures regarding taxing e-commerce (Joumard 2002). There are countries in EU with high VAT rates. The origin principle is applied and the VAT rate for electronic deliveries is the rate of the supplier country. A competitive advantage is obtained by the online sellers from countries with lower VAT compared with those from countries with higher VAT rate. If a client from EU buys an online product from an EU online retailer, the VAT is imposed. On the other hand, if the retailer is outside the EU, there is no fee for transaction. The services for a customer outside the EU are subject to VAT.

The European Commission proposed a directive in 2000 in order to eliminate the discriminations regarding online delivered services. The Commission invited the non-EU providers in electronic commerce system to register in one or more EU countries and to establish the VAT rate corresponding to that EU country. This directive proposed online sales thresholds to eliminate the compliance burden. In Sweden the vendors are required to establish the same VAT rate as that in client country. This was introduced to diminish the competitiveness bias against those countries with high VAT and the non-neutralities between traditional and electronic commerce. 


\section{VAT in European Union and CEE-5 countries}

There is not any uniformity regarding the implementation of European Commission Directives on VAT across EU states. There are procedural complications regarding cross-country differences in the VAT regime which bring trade flows distortions.

For a close economy, let us consider the following relationship:

$$
\mathrm{C}=\mathrm{Y}-\mathrm{S}=\mathrm{W}+\mathrm{R}-\mathrm{I} \text {, }
$$

where Y - total income; C - consumption; S - saving; W - labour income; R - capital income (normal return on capital + economic rents); I - investment.

$\mathrm{W}+\mathrm{R}-\mathrm{I}$ is the value added, representing the base for VAT. At microeconomic level, the value added is computed as the difference between sales and purchases. This value added appears in the profit and loss account and is computed on cash-flow basis. VAT is equivalent to an income net of saving tax, but also to business cash flow and salary tax.

In time, there are two sources for revenue associated to a tax on business cash-flow: the economic rents coming from previous and next investment and normal return on capital. The consumption tax gathers uniform and constant taxes on labour income, old capital and economic rents. There is no tax for normal return on new capital.

For an open economy, the balance of payment identity between capital and current account is used:

$$
\begin{aligned}
& X-M+E=\text { If, which is equivalent to: } \\
& X-M=E-I f
\end{aligned}
$$

where $\mathrm{E}$ - net earnings from abroad; X - exports; $\mathrm{M}$ - imports; If - net investment abroad.

If the imports are included and the exports are excluded, VAT becomes a tax on labour income plus a tax on foreign and domestic capital income, net of new foreign and domestic investment.

The currently used VAT rates in EU are presented in Table 1. The average standard VAT rate in 2015 in EU is over 21\%. In EU states there is a high degree of variation regarding the levels and the numbers of VAT rates. The standard rates of VAT ranges from $15 \%$ for Luxembourg to $27 \%$ in Hungary. The recent debt and financial crisis determined an increase in the standard rate of VAT in the last years (Keuschnigg et al. 2014). So, the competition in commodity taxes has increased. For intra-EU trade a great problem is the fact that there are inefficiencies caused by deferred payment system. Moreover, there is not any convergence in standard rates of VAT.

In SEM-programs the steps to achieve uniformity in excise duties were described. More directives were adopted in order to solve the problems regarding: products that need taxation, minimum tax rates and arrangements regarding taxation.

In CEE-5 countries the following standard rates of VAT were registered in 2009: Bulgaria (20\%), Czech Republic (19\%), Hungary (20\%), Poland (22\%) and Romania (19\%). In 2015, the VAT rate increased with 2 percentage points in Czech Republic, 7 percentage points in Hungary, 1 percentage point in Poland, and 5 percentage points in Romania. The highest increase was observed in Hungary. In Bulgaria the standard rate of VAT remained constant in 2015 compared to 2009. 
Table 1. The standard rate of VAT in EU countries

\begin{tabular}{|c|c|c|}
\hline Country & Standard rate of VAT in $2009(\%)$ & Standard rate of VAT in $2015(\%)$ \\
\hline Belgium & 21 & 21 \\
\hline Bulgaria & 20 & 20 \\
\hline Czech Republic & 19 & 21 \\
\hline Denmark & 25 & 25 \\
\hline Germany & 19 & 19 \\
\hline Estonia & 18 & 20 \\
\hline Greece & 19 & 23 \\
\hline Spain & 16 & 21 \\
\hline France & 19.6 & 20 \\
\hline Croatia & 22 & 25 \\
\hline Ireland & 21.5 & 23 \\
\hline Italy & 20 & 22 \\
\hline Cyprus & 15 & 19 \\
\hline Latvia & 21 & 21 \\
\hline Lithuania & 19 & 21 \\
\hline Luxembourg & 15 & 17 \\
\hline Hungary & 20 & 27 \\
\hline Malta & 18 & 18 \\
\hline Netherlands & 19 & 21 \\
\hline Austria & 20 & 20 \\
\hline Poland & 22 & 23 \\
\hline Portugal & 20 & 23 \\
\hline Romania & 19 & 24 \\
\hline Slovenia & 16 & 22 \\
\hline Slovakia & 19 & 20 \\
\hline Finland & 22 & 24 \\
\hline Sweden & 25 & 25 \\
\hline United Kingdom & 15 & 20 \\
\hline
\end{tabular}

Source: VAT Rates Applied in the Member States of the European Union.

Bulgaria is the country with one of the lowest standard rate of VAT in the Central \& Eastern Europe. The Bulgaria's VAT rate is universal, because there are only some exemptions and reduced VAT rates. According to economists in this case there is a less distorting and more stable tax regime. Bulgaria has a reduced VAT rate of $9 \%$ only for hotel accommodation. The Bulgarian corporate tax rate of $10 \%$ is the lowest from entire EU.

In Czech Republic three amendments of VAT were applied since the $1^{\text {st }}$ January 2015. The first amendment refers to changes regarding Mini-One-Stop-Shop (MOSS). The second modification imposed a second reduced rate of VAT $10 \%$ on some goods. Moreover, some technical issues are solved. The lowest standard rate of VAT, reported by Financial Administration, was registered in Czech Republic in 2004 (19\%). 
Starting from the 1st of July 2009, Hungary imposed a VAT rate of 25\%, increasing with 5 percentage points the previous value. The reduced 5\% VAT rate was kept and a second reduced VAT rate was introduced from the same moment at a rate of $18 \%$. Hungary increased the standard VAT rate from $20 \%$ to $27 \%$ by 2012 in the middle of the financial crisis.

In Poland there is a standard VAT rate of $23 \%$ since 2011. Poland has a reduced VAT rate of $8 \%$ for some goods and services and a reduced VAT rate of $5 \%$ meat, dairy products, fish and poultry.

Romania was forced to fix a rate to $24 \%$ in 2011 . There are a reduced VAT of $9 \%$ for newspapers, books, hotel services and medicines and a reduced rate of $5 \%$ for buildings supply. Recent modifications were brought to Fiscal Code and Romania will have a standard rate of $20 \%$ since the $1^{\text {st }}$ of January 2016 and a rate of $19 \%$ since the $1^{\text {st }}$ of January 2017.

\section{Econometric background}

\subsection{Panel data approach}

Let us consider a regression model based on time and spatial series- pooled ordinary least squares- without any consideration of fixed or random effects:

$$
y_{i t}=\beta_{0}+\sum_{j} \beta_{j} X_{j i t}+e_{i t},
$$

where $i=1,2, \ldots, N ; t=1,2, \ldots, T ; y_{i t}$ - dependent variable at time $t$ for unit $i ; X_{j i t}$ - the $j$-th independent variable at time $t$ for unit $i ; \beta_{j}$ - $j$-th coefficient; $\beta_{0}$ - constant; $e_{i t}$ - error.

This model can be reconsidered in another form for estimating the coefficients using panel data methods. In thic case, fixed effects permi individual effects check. If a specific spatial effect does not vary in time, the unobserved elements are modelled as fixed effects. These individual fixed effects appear in the constant of the model having different values for each unit $\left(\beta_{0 i}\right)$. The unobserved heterogenity is monitored under the hypothesis that it is constant in time and possible correlated with regressors. The one-way fixed effects model is:

$$
y_{i t}=\beta_{0 i}+\sum_{j} \beta_{j} X_{j i t}+e_{i t},
$$

where $i=1,2, \ldots, N ; t=1,2, \ldots, T ; y_{i t}$ - dependent variable at time $t$ for unit $i ; X_{j i t}$ - the $j$-th independent variable at time $t$ for unit $i ; \beta_{j}$ - $j$-th coefficient; $e_{i t}$ - error; $\beta_{0 i}$ - unobserved individual effect for unit $i$ that it is constant in time (it includes the spatial fixed effects).

Unlike the fixed effects model with allows for individual constants,in the random effects model the constant term is a random variable of mean $\beta_{0}$. Spatial differences are seen as random deviations from the constant mean:

$$
\beta_{0 i}=\beta_{0}+\varepsilon_{i},
$$

where $\varepsilon_{i}$ is the error of null mean and constant variance $\sigma_{\varepsilon}^{2}$.

A composite form is observed for the errors:

$$
u_{i t}=\varepsilon_{i}+e_{i t}
$$

where $e_{i t}$ - random error; $\varepsilon_{i}$ - error corresponding to spatial units. 
In general form the random effects model is represented as:

where $i=1,2, \ldots, N, t=1,2, \ldots, T$.

$$
y_{i t}=\beta_{0}+\sum_{j} \beta_{j} X_{j i t}+u_{i t},
$$

The unobserved heterogeneity is given by the demeaning transformation in panel data models. The dynamic panel models delete the unobserved heterogeneity by first differencing. The lagged variable/variables of the model ensures/ensure the adjustment mechanism. The demeaning transformation determines a dependent by error regressor. In case of correlation between explanatory variables and lagged dependent variable, there are biased the coefficients. Nickell bias is observed for fixed-effect model. This bias is present even in case of independent and identically distributed errors. Therefore, the first differences of the initial model are computed. The model with only one explanatory variable and a lagged dependent variable $\mathrm{Y}$ is:

$$
y_{i t}=\beta_{0}+\rho \cdot y_{i, t-1}+\beta_{1} \cdot X_{i t}+u_{i}+\varepsilon_{i t},
$$

where $X_{i t}$ - regressors; $y_{i t}$ - dependent variable; $u_{i}$ - unobserved individual effect; $\varepsilon_{i t}$ - disturbances.

The constant and the individual effect are deleted by constructing the model in first difference:

$$
\Delta y_{i t}=\rho \cdot \Delta y_{i, t-1}+\beta_{1} \cdot \Delta X_{i t}+\Delta \varepsilon_{i t} .
$$

There is still correlation between errors and lagged dependent variable.

Instruments may be built for the lagged dependent variable from the $2^{\text {nd }}$ and the $3^{\text {rd }}$ lag. In case of independent and identically distributed errors, lags are correlated with the lagged dependent variable, but not with composite error.

Let consider the equations:

$$
\begin{gathered}
y_{i t}=\beta_{0} \cdot X_{i t}+\beta_{1} \cdot W_{i t}+v_{i t} ; \\
v_{i t}=u_{i}+e_{i t},
\end{gathered}
$$

where $X_{i t}$ - regressors; $W_{i t}$ - endogenous and predetermined regressors that are correlated with $u_{i}$.

The first-differencing equation will delete the unobserved individual effect.

Generally, a panel vector-autoregressive model is represented as:

$$
y_{n, t}=\mu_{n}+A_{n}(i) \cdot Y_{n, t-1}+\varepsilon_{n, t^{\prime}}
$$

where $Y_{n, t}=\left(y_{1 t^{\prime}}, y_{2 t^{\prime}}, \ldots, y_{N t^{\prime}}\right)$ contains data corresponding to spatial units, $n=1,2, \ldots, N$; $y_{n, t}$ - variables' vector for any spatial unit out of $N$ elements; $\mu_{n}-$ spatial element- specific intercept; $A_{n}(L)$ - lag polynomial with VAR coefficients; $\varepsilon_{n, t^{\prime}}$ - errors (of null average, spatial unit- specific variance $\sigma_{n}^{2}$ ).

In case of no restrictions, matrix $A_{n}$ contains $N \times k \times N$ coefficients.

The VAR models allows for impulse-response analysis. It permits the assessment of the effect of an innovation or a shock in a variable to the other variables of the global system.

In the traditional panel VAR approach, the correlations between spatial units are not considered (Goodhart, Hofmann 2008). A second approach described by Fabio Canova 
and Matteo Ciccarelli makes the VAR's reparametrization to take into account the linkages between spatial units. In order to explain the regressors' modifications, different linear combinations of the explanatory variables are employed (Canova, Ciccarelli 2013).

If the lagged dependent variables parameters differ across spatial units, the standard fixed effect estimator from dynamic panels is not consistent. The errors autocorrelation is computed using the slope coefficients restrictions, in case of auto-correlated regressors. The instrumental variable method does not eliminate the serial correlation. Therefore, Pesaran and Smith recommended for panel VAR the use o mean group estimator (Pesaran, Smith 1995). The parameters across spatial units are average for computing a consistent estimate of mean effects.

The parameters from $A_{n}(L)$ randomly vary across spatial units using the hypothesis of mean group estimator. $a_{n, i, j}^{p}$ in $A_{n}(L)$ is computed as: $a_{n, i, j}^{p}=a_{i, j}^{p}+\mu_{n, i, j}^{p}$, where $\mathrm{p}$ is the lag of the model, $p=1,2, \ldots, P$ and $\mathrm{n}$ is the spatial unit index, $i, j=1,2, \ldots, K$.

In the reduced-form the panel VAR model is:

$$
y_{n, t}=\mu_{n}+A_{n}(L) \cdot y_{n, t}+\varepsilon_{n, t^{\prime}} .
$$

After PVAR coefficients estimation, impulse response functions and variance decompositions are run. The impulse response function is response of an endogenous variable in time when a shock is observed in another variable. Each shock contribution to the variance of the endogenous variable is reflected by variance decomposition at prediction horizon.

\subsection{Bayesian regression}

The matrix form of the regression model is established:

$$
Y_{t}=A X_{t}+u_{t}, \text { where } u_{t} \rightarrow N\left(0, \sigma^{2}\right),
$$

where $k$ - number of independent variables; $n$ - observations' number; $t$ - index for time; $Y$ - dependent variable with $n \times 1$ elements; $X$ - matrix of independent variables with $n \times \mathrm{k}$ elements; $u$ - errors; $\sigma^{2}$ - variance of errors.

The main aim is to determine the estimators' matrix. The traditional Econometrics estimates and maximizes the likelihood function in order to find out the estimator of matrix A and the estimated errors' variance. So, all data are employed in traditional econometric methods.

Several stages are followed in the Bayesian approach:

1. The researcher have some intuitions regarding the values of estimators, using the data for the matrix A and for the errors' variance, but these are different from the data series for $\mathrm{X}$ and $\mathrm{Y}$. These intuitions are known as prior believes. These intuitions are related to the experience of the researcher and to previous analyses for the same models based on other data. These beliefs are known as probability distributions. We may consider that the prior of matrix A coefficients has a normal distribution of mean $A_{0}$ and of variance-covariance matrix $\sum_{0}$. If the researcher is quite sure about this/her appreciations related to the coefficients value, he/she will provide a low variance. 
2. This stage is common with that from classic Econometrics supposing the collection of the data for the model's variables and the likelihood function estimation:

$$
F\left(Y_{t} \backslash A, \sigma^{2}\right)=\left(2 \pi \sigma^{2}\right)^{-\frac{T}{2}} \cdot \exp \left(-\frac{\left(Y_{t}-A X_{t}\right)^{T}\left(Y_{t}-A X_{t}\right)}{2 \sigma^{2}}\right) .
$$

3. The expectations related to the model parameters based on data for $\mathrm{X}$ and $\mathrm{Y}$ and the estimated likelihood function are updated. In practice, the posterior probability distribution is computed as the product between likelihood function and prior distribution. This repartition is computed in terms of Bayesian theorem as:

$$
H\left(A, \sigma^{2} \backslash Y_{t}\right)=\frac{F\left(Y_{t} \backslash A, \sigma^{2}\right) \cdot P\left(A, \sigma^{2}\right)}{F(Y)} .
$$

So, the prior distribution is calculated like a ratio of two elements: the product between prior probability and likelihood function and the marginal likelihood (this is the data marginal density, being a scalar). Prior distribution is proportional with likelihood function by a prior number of times. For estimating the simple regression model parameters, the next relationship is employed:

$$
H\left(A, \sigma^{2} \backslash Y_{t}\right) \alpha F\left(Y_{t} \backslash A, \sigma^{2}\right) \cdot P\left(A, \sigma^{2}\right) .
$$

The joint density is computed as product between marginal density of $\mathrm{Y}$ and the parameters of the conditional density. Another way to compute the joint density is the product between coefficients marginal density and data conditional density:

$$
G\left(Y_{t}, A, \sigma^{2}\right)=F\left(Y_{t}\right) \times H\left(A, \sigma^{2} \backslash Y_{t}\right)=F\left(Y_{t} \backslash A, \sigma^{2}\right) \cdot P\left(A, \sigma^{2}\right) .
$$

\section{Economic growth and VAT rate in CEE-5 countries}

The data refer to real GDP rate (\%) and standard rate of VAT (\%) in CEE-5 countries (Bulgaria, Czech Republic, Hungary, Poland and Romania) over the period 1995-2015. The econometric techniques cover panel data models (random effects models, dynamic panel models and panel VAR models), but also Bayesian linear regression models that solve the problem of a small set of data for each country.

First of all, the stationary character of panel data is checked using specific unit root tests (Im-Pesaran- Shin- IPS test and Fisher type test). There are not enough proofs to reject the hypothesis that some panels are stationary at a significance level of 5\%, according to results from Table 2 .

Table 2. The results of unit root tests

\begin{tabular}{lcccc}
\hline \multirow{2}{*}{ Unit root test } & \multicolumn{2}{c}{ GDP rate } & \multicolumn{2}{c}{ VAT rate } \\
\cline { 2 - 5 } & Statistic & p-value & Statistic & p-value \\
\hline Im-Pesaran-Shin & -2.91 & 0.018 & - & - \\
\hline Fisher- type & 4.5166 & 0.000 & 2.0631 & 0.0196 \\
\hline
\end{tabular}

Source: authors' calculations. 
A random effect model without intercept was estimated using as estimation method the maximum likelihood (ME). A dynamic panel model with a single lag for GDP rate was proposed, using Arrelano-Bover/Blundell-Bond estimators. Moreover, a panel vectorautoregression (panel VAR) of order 1 was proposed for the mentioned variables. The following equations were obtained for the proposed panel data models:

$$
\begin{aligned}
& \mathrm{GDP}_{\text {rate }} \text { it }=0,1273 \cdot \mathrm{VAT} \_r a t e_{i t} \text {; } \\
& \mathrm{GDP} \text { rate }_{i t}=0,0829 \cdot \mathrm{VAT} \_ \text {rate }_{i t}+0,784 \cdot \mathrm{GDP} \_ \text {rate }_{i t-1} \text {; } \\
& \mathrm{GDP}_{\text {rate }}{ }_{i t}=0,9228 \cdot \mathrm{VAT} \_ \text {rate }_{i t-1}-0,3485 \cdot \mathrm{GDP} \text { rate }_{i t-1} \text {. }
\end{aligned}
$$

All the proposed panel models indicated a positive impact of VAT rate in actual period and GDP rate in previous period on the economic growth in the current period. So, the increase in VAT rates will generate economic growth. The dynamic model (M2) showed that GDP rate in the previous period positively influenced the current economic growth. However, the panel VAR model (M3) indicated a negative impact on previous GDP rates on actual economic growth taking into account the negative effects of economic crisis.

The results of Granger causality test in panel data (Table 3) put into evidence a bidirectional causality between GDP rate and the standard rate of VAT in CEE countries for a significance level of $5 \%$.

Table 3. Panel-VAR Granger causality Wald test

\begin{tabular}{lcc}
\hline \multicolumn{1}{c}{ Equation/Excluded } & Chi-square & Prob. \\
\hline GDP_rate & & \\
VAT_rate & 6.014 & 0.014 \\
All & 6.014 & 0.014 \\
\hline VAT_rate & & \\
GDP_rate & 14.94 & 0.00 \\
All & 14.94 & 0.00 \\
\hline
\end{tabular}

Source: authors' calculations.

Some Bayesian regression models were proposed to explain the real GDP rate using the standard rate of VAT for each country. Conditional posteriors are inverted gamma (the variance follows an Inverse Gamma repartition of parameters "a" and "b") and conjugate normal (for the coefficients we have a normal distribution of parameters $m$ (the mean) and $\mathrm{V}$ (variance-covariance matrix)). The prior for $\mathrm{a}$ and $\mathrm{b}$ are set to 0 . Conditional posterior variance follows an Inverse Gamma distribution of parameters $n / 2+a$ and $2 b /(b$ * $R S S+$ 2) respectively, where RSS is the sum squares of residual values.

In Table 4, the posterior mean for constant and VAT rate's coefficient are presented.

The estimation of coefficients' posterior means indicated that in average only in Hungary VAT rate has a positive impact on economic growth. In the other countries, the increase in VAT rates will negatively affect the economic growth. So, the solution for increasing GDP rate in these countries is to diminish the standard VAT rate. 
Table 4. Bayesian linear regression models for explaining GDP rate in CEE-5 countries

\begin{tabular}{lcc}
\hline \multicolumn{1}{c}{ Country } & Posterior mean of constant & Posterior mean of slope \\
\hline Bulgaria & 2.7766 & -0.0028 \\
\hline Czech Republic & 3.0345 & -0.0357 \\
\hline Hungary & -6.0894 & 0.3407 \\
\hline Poland & 7.8121 & -0.1695 \\
\hline Romania & 7.8372 & -0.2525 \\
\hline
\end{tabular}

Source: authors' calculations.

The Romanian Parliament confirmed established in August 2015 that the standard VAT rate will be cut from $24 \%$ (the value used from the $1^{\text {st }}$ of July 2010 , in the middle of financial crisis) to $20 \%$ on 1 January 2016. For 2018, the Parliament intended to reduce the VAT to $18 \%$. This cut in VAT in Romania will increase the budget deficit, the consumption rate, the retail and the inflation rate. In Czech Republic and Bulgaria VAT is expected to keep the values from 2015 (a standard VAT rate of $21 \%$, respectively $20 \%$ ). Poland will reduce its VAT from $23 \%$ to $22 \%$ in 2016 . Hungary is the country with the highest standard VAT in European Union. In 2016 a decrease with 5 percentage points is expected (a VAT rate of $22 \%)$. In simulations from Table 5, the forecasts of GDP growth made by European Commission are used.

Table 5. Simulations of GDP rate in CEE-5 countries using random effects model

\begin{tabular}{lccc}
\hline \multicolumn{1}{c}{ Country } & Year & Standard rate of VAT & Simulation for GDP rate (\%) \\
\hline \multirow{2}{*}{ Bulgaria } & 2016 & $20 \%$ & $2.55 \%$ \\
\cline { 2 - 4 } & 2018 & $20 \%$ & $2.55 \%$ \\
\hline Czech Republic & 2016 & $21 \%$ & $2.67 \%$ \\
\cline { 2 - 4 } & 2018 & $21 \%$ & $2.67 \%$ \\
\hline Hungary & 2016 & $22 \%$ & $2.80 \%$ \\
\hline Poland & 2018 & $22 \%$ & $2.80 \%$ \\
\hline Romania & 2016 & $22 \%$ & $2.80 \%$ \\
\hline & 2018 & $22 \%$ & $2.80 \%$ \\
\hline
\end{tabular}

Source: authors' calculations.

For Romania, the decrease of TVA rate will generate a lower economic growth, according to the simulations for 2016 and 2018. For the rest of the countries the maintenance of the same standard rate of VAT for 2016 and 2018 will ensure the same economic growth. Compared to the expectations for 2015, Bulgaria, Romania and Hungary will register a higher GDP rate in 2016. On the other hand, a lower value than the expectation for 2015 is anticipated for Czech Republic in 2016 (see Table 6). 
Table 6. Simulations of GDP rate in CEE-5 countries using dynamic panel model

\begin{tabular}{lccc}
\hline \multicolumn{1}{c}{ Country } & Year & Standard rate of VAT & Simulation for GDP rate (\%) \\
\hline \multirow{2}{*}{ Bulgaria } & 2016 & $20 \%$ & $0.50 \%$ \\
\cline { 2 - 4 } & 2018 & $20 \%$ & $0.80 \%$ \\
\hline Czech Republic & 2016 & $21 \%$ & $2.13 \%$ \\
\cline { 2 - 4 } & 2018 & $21 \%$ & $2.13 \%$ \\
\hline Hungary & 2016 & $22 \%$ & $1.98 \%$ \\
\hline Poland & 2018 & $22 \%$ & $1.59 \%$ \\
& 2016 & $22 \%$ & $2.21 \%$ \\
\hline Romania & 2018 & $22 \%$ & $1.82 \%$ \\
\hline & 2016 & $20 \%$ & $2.21 \%$ \\
\hline
\end{tabular}

Source: authors' calculations.

The results based on dynamic model indicated lower GDP rates for all CEE- 5 countries compared to the simulations based on random-effects model. For Hungary, Poland and Romania lower simulations of GDP rates were obtained in 2018 compared to the values for 2016. However, the maintenance of the same standard rate of VAT in 2018 will bring a higher economic growth (see Table 7).

Table 7. Simulations of GDP rate in CEE-5 countries Bayesian linear regression models

\begin{tabular}{lccc}
\hline \multicolumn{1}{c}{ Country } & Year & Standard rate of VAT & Simulation for GDP rate (\%) \\
\hline \multirow{2}{*}{ Bulgaria } & 2016 & $20 \%$ & $2.78 \%$ \\
\cline { 2 - 4 } & 2018 & $20 \%$ & $2.78 \%$ \\
\hline Czech Republic & 2016 & $21 \%$ & $3.03 \%$ \\
\cline { 2 - 4 } & 2018 & $21 \%$ & $3.03 \%$ \\
\hline Hungary & 2016 & $22 \%$ & $6.02 \%$ \\
\hline Poland & 2018 & $22 \%$ & $6.02 \%$ \\
\hline Romania & 2016 & $22 \%$ & $7.77 \%$ \\
\hline & 2018 & $22 \%$ & $7.77 \%$ \\
\hline
\end{tabular}

Source: authors' calculations.

For Hungary, Poland and Romania the simulated GDP rates based on Bayesian regression for 2016 and 2018 are greater than 6\%, a quite implausible situation. However, the Bayesian model anticipated high rates than the values in 2015. The decrease of standard rate of VAT in 2018 compared to 2016 in Romania will generate an insignificant increase in GDP rate. 


\section{Conclusions}

The panel data models suggested for CEE-5 countries during 1995-2015 a positive influence of VAT rate on economic growth. The individual analysis on countries using Bayesian approach showed a positive influence of VAT rate on GDP rate only for Hungary, the country with the highest standard rate of VAT from EU. For the rest of the countries (Bulgaria, Czech Republic, Poland and Romania) there is a slow negative impact of VAT rate on economic growth.

In Hungary, the decrease of VAT rate will generate economic growth. This result is in accordance with the economic framework in this country that has the highest standard rate of VAT from EU. Therefore, the European Commission required Hungary to decrease its huge VAT rate and this will have positive effects on GDP rate.

Combining the results of the two approaches, we can state that on long run the increase in VAT rate positively affects economic growth in all CEE- 5 countries, while on short-run the increase in VAT rate will generate problems in collecting the consumption taxes and the GDP rate will reduce. In Romania, from 2016 a VAT rate of $20 \%$ will be applied and a rate of $18 \%$ is expected for 2018 . The decrease in standard rate of VAT for this country will generate a decrease in GDP rate according to simulations based on panel data models and an insignificant increase according to Bayesian approach.

\section{References}

Altshuler, R; Goodspeed, T. J. 2003. Follow the leader? Evidence on European and US tax competition, Public Finance Review 43(4): 485-504. http://dx.doi.org/10.1177/1091142114527781

Baskaran, T.; da Fonseca; M. L. 2014. The economics and empirics of tax competition: a survey and lessons for the EU, Erasmus Law Review 7(1):1-23. http://dx.doi.org/10.5553/elr.000015

Bénassy-Quéré, A.; Fontagné, L.; Lahrèche-Révil, A. 2005. How does FDI react to corporate taxation?, International Tax and Public Finance 12(5): 583-603. http://dx.doi.org/10.1007/s10797-005-2652-4

Borselli, F.; Chiri, S.; Romagnano, E. 2012. Patterns of reduced VAT rates in the European Union, International VAT Monitor 23(1): 13-21.

Canova, F.; Ciccarelli, M. 2013. Panel Vector Autoregressive Models: a survey. The views expressed in this article are those of the authors and do not necessarily reflect those of the ECB or the Eurosystem, in Thomas B. Fomby, Lutz Kilian, Anthony Murphy (Eds.). VAR Models in Macroeconomics - New Developments and Applications: Essays in Honor of Christopher A. Sims. Bingley: Emerald Group Publishing Limited.

Carroll, R. 2010. The macroeconomic effects of an add-on value added tax. National Retail Federation. Washington, DC: Ernst \& Young LLP.

Cnossen, S. 2002. Tax policy in the European Union: a review of issues and options, Finanz Archiv/ Public Finance Analysis 15: 466-558. http://dx.doi.org/10.1628/0015221022905803

Devereux, M. P.; Lockwood, M.; Redoano, M. 2008. Do countries compete over corporate tax rates?, Journal of Public Economics 92(5): 1210-1235. http://dx.doi.org/10.1016/j.jpubeco.2007.09.005

Egger, P.; Pfaffermayr, M.; Winner, H. 2005. Commodity taxation in a "linear" world: a spatial panel data approach, Regional Science and Urban Economics 35(5): 527-541.

http://dx.doi.org/10.1016/j.regsciurbeco.2004.07.004 
Genschel, P.; Kemmerling, A.; Seils, E. 2011. Accelerating downhill: how the EU shapes corporate tax competition in the single market, Journal of Common Market Studies 49(3): 585-606. http://dx.doi.org/10.1111/j.1468-5965.2010.02136.x

Goodhart, C.; Hofmann, B. 2008. House prices, money, credit, and the macroeconomy, Oxford Review of Economic Policy 24(1): 180-205. http://dx.doi.org/10.1093/oxrep/grn009

Heinemann, F.; Overesch, M.; Rincke, J. 2010. Rate-cutting tax reforms and corporate tax competition in Europe, Economics \& Politics 22(3): 498-518. http://dx.doi.org/10.1111/j.1468-0343.2010.00375.x

Jalata, D. M. 2014. The role of value added tax on economic growth of Ethiopia, Science, Technology and Arts Research Journal 3(1): 156-161. http://dx.doi.org/10.4314/star.v3i1.26

Joumard, I. 2002. Tax systems in European Union countries, OECD Economic Studies 34: 91-151. http://dx.doi.org/10.1787/eco_studies-v2002-art4-en

Keen, M.; Konrad, K. A. 2014. The theory of international tax competition and coordination, Chapter 5 in A. J. Auerbach, R. Chetty, M. Feldstein, E. Saez (Eds.). Handbook of Public Economics. Amsterdam: Elsevier Science B.V.

Kersan-Škabić, I. 2015. Taxation for FDI attractiveness of Southeast European countries, Panoeconomicus 62(1): 105-122. http://dx.doi.org/10.2298/PAN1501105K

Keuschnigg, C.; Loretz, S.; Winner, H. 2014. Tax competition and tax coordination in the European Union: a survey, Working Papers in Economics and Finance 4: 1-30.

Miki, B. 2011. The effect of the VAT rate change on aggregate consumption and economic growth, Center on Japanese Economy and Business Working Papers 297: 1-30.

Njogu, L. K. 2015. The effect of value added tax on economic growth in Kenya, International Academic Journal of Economics and Finance 1(5): 10-30.

Onwuchekwa, J. C.; Aruwa, S. 2014. The value added tax and economic growth in Nigeria, European Journal of Accounting Auditing and Finance Research 2(8): 62-69.

Osterloh, S.; Heinemann, F. 2013. The political economy of corporate tax harmonization - why do European politicians (dis) like minimum tax rates?, European Journal of Political Economy 29: 18-37. http://dx.doi.org/10.2139/ssrn.1328874

Pesaran, M. H.; Smith, R. 1995. Estimating long-run relationships from dynamic heterogeneous panels, Journal of Econometrics 68(1): 79-113. http://dx.doi.org/10.1016/0304-4076(94)01644-F

Rademacher, I. 2013. Tax competition in the euro zone: capital mobility, agglomeration, and the small country disadvantage, MPIfG Discussion Paper 13: 1-25.

Reckon, L. L. P. 2009. Study to quantify and analyse the VAT gap in the EU-25 Member States, Report for DG Taxation and Customs Union 20: 5-109. http://dx.doi.org/10.2139/ssrn.2693524

Redoano, M. 2014. Tax competition among European countries. Does the EU matter?, European Journal of Political Economy 34: 353-371. http://dx.doi.org/10.1016/j.ejpoleco.2014.02.006

Umeora Chinweobo, E. 2013. The effects of Value Added Tax (VAT) on the economic growth of Nigeria, Journal of Economics and Sustainable Development 4(6): 190-201. http://dx.doi.org/10.2139/ssrn.2285329

Unegbu, A. O.; Irefin, D. 2011. Impact of VAT on economic development of emerging nations, Journal of Economics and International Finance 3(8): 492-503.

Wolff, G. B. 2007. Foreign direct investment in the enlarged EU: do taxes matter and to what extent?, Open Economies Review 18(3): 327-346. http://dx.doi.org/10.1007/s11079-007-9041-9

Zídková, H. 2014. Determinants of VAT Gap in EU, Prague Economic Papers 2014(4): 514-530. http://dx.doi.org/10.18267/j.pep.496 
Mihaela SIMIONESCU is Habilitated Doctor in Economics (2016), PhD in Economic Statistics, Senior Researcher at the Institute for Economic Forecasting of the Romanian Academy, Member of the Romanian Society of Econometrics, Romanian Regional Science Association and International Regional Science Association, General Association of Economists from Romania, International Association of Scientific Innovation and Research (IASIR), Internet Society, Interoperability Solutions for European Public Administrations, EcoMod Network. Author of more than 200 publications (articles, books, conference papers). Main research area: Macroeconomic modelling and forecasting, Forecasts uncertainty, Foreign Direct Investment.

Lucian-Liviu ALBU is Academician, $\mathrm{PhD}$ in Economics and $\mathrm{PhD}$ supervisor in the Economics, Director and Senior Researcher at the Institute for Economic Forecasting of the Romanian Academy. Participation (as partner or coordinator of national research teams) in more than 30 international research projects financed by programmes from EU (ACE-PHARE, Research Grants, PHARE, FP7, IDEI), World Bank, UNDP, USAID, GDN, etc., and in more than 40 national projects (including Romanian Academy's annual research programmes). Membership of professional bodies: National Fiscal Council, Bucharest; Network of British Academy Beneficiaries of Research Stages; Scientific Council of NIER, Romanian Academy; International Association of National Accountability, INSEE, Paris; Romanian Society of Economics, Bucharest; Adam Smith Institute, London; Quantitative Macroeconomics and Real Business Cycle theory; Coordinating Council of Statistical Activity, National Institute of Statistics, Bucharest; Global Development Network, New York, Prague, Vienna; Commission of SocioEconomic Cybernetics, Romanian Academy; Centre for Research on Emerging Economies, Staffordshire University, Stoke on Trent; Romanian Association for the Club of Rome; EcoMod Network, Free University of Brussels; Network on Employment and Gender Equality Issues, EC, Brussels, etc. Founder and Chief Editor of the Romanian Journal of Economic Forecasting (ISI Journal) and member of the editorial board at more than 20 international economic journals. Publications: more than 40 WorldCat indexed books and monographs (as author, co-author or editor), more than 300 articles (indexed in ISI - Thomson Reuters, RePEc and other scientific databases) and chapters in books (in Romanian, in English, and in French), more than 100 papers presented at international conferences. Main research area: Modern economic theory and non-linear macroeconomics, Models on informal economy and tax evasion, Economic efficiency and development, Econometric modelling and forecast. 